\title{
THE ROHINGYA GENOCIDE CASE (THE GAMBIA $V$ MYANMAR): BREACH OF OBLIGATIONS ERGA OMNES PARTES AND THE ISSUE OF STANDING
}

\author{
Abdul Ghafur Hamid *
}

\begin{abstract}
On 23rd January 2020, the International Court of Justice indicated provisional measures to protect the Rohingya from the alleged genocidal acts committed in Myanmar. Rejecting the argument made by Myanmar, the World Court decided that The Gambia has standing before the court although it was not directly injured by the alleged wrongful act. The court applied the concept of "obligations erga omnes partes" in the context of its ruling on standing. The court, however, did not elaborate more on the concept and did not touch on its details. Since this case had attracted so much international attention, the concept has become a trending topic for legal discourse. This article, therefore, is an attempt to resolve the issues of whether the concept of obligations erga omnes partes has been established as a rule of customary international law and whether such an obligation may arise from any type of multilateral treaty and any provision in a multilateral treaty. To this end, the article analyses the jurisprudence of the International Court of Justice (ICJ), the case law of international human rights courts and the work and the valuable commentary of the International Law Commission on Article 48 of the Articles on the Responsibility of States for Internationally wrongful Act 2001. The article concludes that the concept of obligations erga omnes partes has been established as a rule of customary international law, that it may arise from any type of multilateral treaty and that it is applicable only in relation to the provision of a treaty that is essential to the accomplishment of object and purpose of the treaty.
\end{abstract}

Keywords: obligations erga omnes partes, Rohingya genocide case, interim measures of protection, standing before courts.

* Professor, Department of Civil Law, Ahmad Ibrahim Kuliyyah of Laws, International Islamic University of Malaysia. Email: ghafur@iium.edu.my.

[Received: 2 May 2021, Accepted:26 May 2021, Published:30 June 2021] 


\title{
KES PEMBUNUHAN BERAMAI-RAMAI DI ROHINGYA (GAMBIA LWN MYANMAR): PELANGGARAN TANGGUNGJAWAB ERGA OMNES PARTES DAN KEDUDUKAN UNDANG-UNDANG
}

\begin{abstract}
ABSTRAK
Pada 23 Januari 2020, Mahkamah Antarabangsa mengumumkan langkah-langkah sementara untuk melindungi pelarian Rohingya dari pembunuhan beramai-ramai yang dilakukan di Myanmar. Menolak hujah yang dibuat oleh Myanmar, Mahkamah Dunia memutuskan bahawa Gambia mempunyai hak untuk membawa Myanmar ke muka pengadilan walaupun ia tidak terkesan secara langsung oleh tindakan Myanmar yang didakwa menyalahi undang-undang antarabangsa. Mahkamah menerapkan konsep "kewajiban erga omnes partes" dalam konteks keputusannya untuk memberi kuasa mendengar kes tersebut. Mahkamah, bagaimanapun, tidak menjelaskan lebih lanjut mengenai konsep itu dan tidak memberi perincian berkenaan asbab keputusan tersebut. Oleh kerana kes ini telah menarik banyak perhatian antarabangsa, konsep ini telah menjadi topik penting untuk wacana undang-undang. Oleh itu, makalah ini adalah usaha untuk menyelesaikan masalah apakah konsep kewajiban yang telah ditetapkan oleh erga omnes partes sebagai peraturan undang-undang antarabangsa. Makalah ini turut mengkaji samada kewajiban tersebut timbul dari pelbagai jenis perjanjian multilateral dan peruntukan dalam perjanjian pelbagai hala. Untuk tujuan ini, makalah ini menganalisa undang-undang Mahkamah Antarabangsa, undang-undang hak asasi manusia antarabangsa, dan komentar berharga dari Suruhanjaya Undang-Undang Antarabangsa mengenai Artikel 48, Artikel mengenai Tanggungjawab Negara-negara di peringkat antarabangsa 2001. Makalah ini menyimpulkan bahawa konsep kewajiban erga omnes partes telah ditetapkan sebagai peraturan undang-undang antarabangsa, bahawa ia mungkin timbul dari segala jenis perjanjian multilateral dan ianya hanya terpakai terhadap bahagian perjanjian tersebut setakat mana ianya perlu bagi mencapai objektif dan tujuan perjanjian.
\end{abstract}

Kata kunci: $\quad$ kewajiban erga omnes partes, kes pembunuhan Rohingya, sementara langkah perlindungan kedudukan undang-undang. 


\section{INTRODUCTION}

The Rohingya, an ethnic Muslim group from Rakhin state, Myanmar, are identified by the United Nations as the most persecuted people of the world. ${ }^{1}$ The Rohingya are being discriminated against based on their ethnicity and religion. Myanmar, a Buddhist majority country, has persecuted the Rohingya for more than half a century. The persecution increased since 1962 after the military coup by the dictator General Newin. The worst form of discrimination is that the Rohingya, whose forefathers had lived in Myanmar for centuries, have become stateless by virtue of the Citizenship Law of $1982 .^{2}$

After the discriminatory Citizenship Law, Myanmar launched massive immigration operations against the Rohingya in the Rakhine state, forcing hundreds of thousands of the Rohingya to flee to countries like Bangladesh, Malaysia, Thailand, and many others. ${ }^{3}$ In 2016, after the attack by a few Rohingya against three police outposts in Rakhine, the Myanmar military conducted the so-called 'clearance' operations in the Rakhine State. ${ }^{4}$ Due to these cruel and inhumane activities, most of the remaining Rohingya in the Rakhine State were forced to flee to the neighbouring Bangladesh, creating one of the worst refugee problems in the world.

Following a decision of the Organization of Islamic Cooperation (OIC), on 11 November 2019, The Gambia brought a legal action against Myanmar before the International Court of Justice (ICJ) for alleged violations of the Genocide Convention. ${ }^{5}$ The Gambia also

1 Kiragu, E., Rosi, A. L., \& Morris, T., "States of Denial: A Review of UNHCR's Response to the Protracted Situation of Stateless Rohingya Refugees in Bangladesh," Policy Development and Evaluation Services (UNHCR, Geneva: Switzerland, December 2011).

2 Azad, A., \& Jasmine, F., "Durable Solutions to the Protracted Refugee Situation: The Case of Rohingyas in Bangladesh," Journal of Indian Research, 1(4) (2013): 25-35.

3 Haradhan Kumar Mohajan, "History of Rakhine State and the Origin of the Rohingya Muslims," IKAT: The Indonesian Journal of Southeast Asian Studies, 2(1) (2018): 19-46, at 32.

4 See generally UN Fact- Finding Mission, Report of the Detailed Findings (2018), paras. 1069-1095; UN OHCHR, Flash Report (2017), pp. 13-40.

5 Convention on the Prevention and Punishment of the Crime of Genocide (adopted 9 December 1948, 
applied for interim measures of protection. During the proceedings, the International Court of Justice rejected Myanmar's argument that The Gambia had no standing to initiate proceedings as it was not an injured State. The ICJ decided that the object and purpose of the Genocide Convention is to prevent and punish genocide, which is an obligation erga omnes partes and thus any State party to the convention, including The Gambia, has standing to institute proceedings against any other State party that violated the obligation.

The ICJ's affirmation of the concept of obligations erga omnes partes by unanimous decision has sparked a heated discussion regarding the characteristics and modalities of such an obligation that can create standing before international courts by a State, which is not an injured State under the traditional law of State responsibility. The present work is an attempt to ponder upon the unresolved issues such as the customary international law status of obligations erga omnes partes, the type of treaties where one can find such obligations and whether all provisions in these treaties may amount to such an obligation. In doing so, the present work relies on the jurisprudence of the ICJ, the case law of international human rights courts, and the valuable commentary of the International Law Commission on Article 48 of the Articles on the Responsibility of States for Internationally wrongful Act 2001.

\section{BACKGROUND OF THE CASE}

The Rohingya are Muslim ethnic minorities in Myanmar, a predominantly Buddhist country. They live in Rakhine state (also known as Arakan), a western coastal area of Myanmar, which is bordering with Bangladesh. ${ }^{6}$

entered into force 12 January 1951), 78 UNTS 277 [hereinafter “Genocide Convention"].

6 See Application Instituting Proceedings and Request for Provisional Measures, filed by The Gambia on 11 November 2019, 2019 General List No. 179, the International Court of Justice, [Hereinafter Application Instituting Proceedings, The Gambia v Myanmar, 2019], para. 27. 


\section{The origin of the Rohingya}

A Scottish surgeon, working with the British East India Company, by the name of Francis Buchanan, traveled to Burma (the former name of Myanmar) in 1799. He confirmed that he had a chance to meet members of a Muslim ethnic group, who had long settled in Rakhine and called themselves Roainga (meaning natives of Arakan). ${ }^{7}$ Michael W. Charney affirmed that the ethnonym 'Rohingya' is derived from the root word 'Roainga,' which can be traced to the $17^{\text {th }}$ century. ${ }^{8}$

Researchers believe that the first Muslim arrival to Arakan was in the 8th century and a distinct Arakanese Muslim community was established in the 15th and 16th centuries through later expansion of their population. ${ }^{9}$ Another point of view that is held by the Myanmar authorities is that the Rohingya are Bengalis illegally migrated from Bangladesh. ${ }^{10}$ Nevertheless, what is clear from the solid historical facts is that the Rohingya have been the Muslim natives of the Rakhine State for centuries although there may be later additions to their population by migrants from Bangladesh due to the loose immigration enforcement. ${ }^{11}$

7 Buchanan, F. "A Comparative Vocabulary of Some of the Languages Spoken in the Burma Empire," Asiatic Researchers, 5 (1979): 219-240. Retrieved from www.soas.ac.uk/sbbr/editions/file64276.pdf. Buchanan's original article was reproduced in SOAS Bulletin of Burma Research, Vol. 1, No., 1, Spring 2003.

8 Charney, M. W. (2005). "Buddhism in Arakan: Theories and Historiography of the Religious Basis of Ethnonyms." Paper Presented at the Arakan History Conference, Bangkok: Thailand (2005); published in Kaladan Press Network, Scholar Column, 8 July 2007, https://www.kaladanpress.org/index.php/scholar-column-mainmenu36/58-arakan-historical-seminar/718-buddhism-in-arakantheories-andhistoriography-ofthe-religious-basis-of-ethnonyms.html.

9 Grundy-Warr, C., \& Wong, E. "Sanctuary under a Plastic Sheet - The Unresolved Problem of Rohingya Refugees" IBRU Boundary and Security Bulletin. Autumn (1997), 79-91, at 80.

10 Bahar A.S. (1981). The Arakani Rohingyas in Burmese Society. Master Thesis (Unpublished), University of Windsor, Ontario, Canada, 24-25.

11 Haradhan Kumar Mohajan, "History of Rakhine State and the Origin of the Rohingya Muslims," IKAT:The Indonesian Journal of Southeast Asian Studies, (2018) vol. 2, No.1, July 2018, 19-46, at 14. 


\section{Genocidal intent and genocidal acts against the Rohingya}

Evidence of genocidal intent can be found in discriminatory policies of the successive Myanmar governments against the Rohingya. The 1982 Citizenship Law, for example, makes citizenship dependent on belonging to one of the national races recognized by the government. ${ }^{12}$ Applying the controversial Citizenship Law, the Rohingya are not a national race and can never be a citizen of Myanmar. ${ }^{13}$ This policy effectively makes the Rohingya stateless. What is worst, the Myanmar government even objects to the very use of the name 'Rohingya,' and holds as the State policy to call them as 'Bengali,' suggesting that they do not belong to Myanmar and that they are illegal immigrants from the neighbouring Bangladesh. ${ }^{14}$

Due to the extremely discriminating and segregated policy of the government against the Rohingya, these vulnerable people have no basic human rights such as the right to religion, right to livelihood, right to education and so on. They are even subjected to severe restrictions on their freedom of movement. They cannot freely move from one village to another. Many of them are confined in displacement camps, surrounded by barbed wires, and cut off from the outside world. ${ }^{15}$

The immediate event that led to the massive exodus of the Rohingya from Myanmar to Bangladesh in 2017 was the so-called "Clearance Operations" made by the Myanmar military after a small number of Rohingya attacked border guard police posts. Myanmar armed forces shot, killed, raped, gang-raped, and tortured Rohingya civilians and burned down and destroyed Rohingya homes, mosques, madrasas, and villages. ${ }^{16}$

12 See UN Human Rights Council, Report of the Independent International Fact- Finding Mission on Myanmar (12 September 2018), UN doc. A/HRC/39/64, para. 4; UN Human Rights Council, Report of the Detailed Findings of the Independent International Fact- Finding Mission on Myanmar (17 September 2018), UN doc. A/HRC/39/CRP.2 [hereinafter UN Fact- Finding Mission, Report of the Detailed Findings (2018)] paras. 477-479, 1425.

13 Ibid., para. 460.

14 Ibid.

15 Ibid., para 517.

16 UN Fact- Finding Mission, Report of the Detailed Findings (2018), paras. 1069-1095; UN OHCHR, Report of OHCHR Mission to Bangladesh: 
The genocidal intent of these crimes was confirmed by multiple UN investigations. Professor Yanghee Lee, the UN Special Rapporteur on Human Rights in Myanmar, carried out extensive fact-finding regarding Myanmar's persecution against the Rohingya and concluded that "the crimes committed in Myanmar bear the hallmarks of genocide." 17

The UN Human Rights Council's Independent International Fact-Finding Mission on Myanmar also concluded that the factors allowing the inference of genocidal intent are present and stated that the situation in Myanmar is an ongoing genocide. ${ }^{18}$

\section{INITIATING PROCEEDINGS BEFORE THE ICJ AND REQUEST FOR INTERIM MEASURES OF PROTECTION}

The Rohingya issue was deliberated in March 2019 at a meeting of the Organization of Islamic Cooperation (OIC). A unanimous resolution was adopted by the OIC Council of Foreign Ministers to bring the case to the International Court of Justice (ICJ) for the establishment of the legal rights of the Rohingya. The Gambia willingly accepted to initiate

Interviews with Rohingyas Fleeing from Myanmar since 9 October 2016: Flash Report (3 February 2017), available at https://www.ohchr.org/Documents/Countries/MM/FlashReport3Feb201 7.pdf. pp. 7, 13-40.

17 UN OHCHR, "Statement by Ms Yanghee Lee, Special Rapporteur on the situation of human rights in Myanmar at the 37th session of the Human Rights Council" (12 March 2018), available at https://www.ohchr.org/en/NewsEvents/Pages/DisplayNews.aspx?NewsI $\mathrm{D}=22806 \&$ LangID=E. See also UN Secretary- General, Note to Correspondents: Statement by Adama Dieng, United Nations Special Adviser on the Prevention of Genocide, on his visit to Bangladesh to assess the situation of Rohingya refugees from Myanmar (12 March 2018), available at https:// www.un.org/sg/en/content/sg/notecorrespondents/2018-03-12/note- correspondentsstatement-adama-diengunited-nations.

18 UN Fact- Finding Mission, Report of the Detailed Findings (2018)], paras. 4, 1441. "Rohingya genocide is still going on, says top UN investigator", The Guardian (24 October 2018), available

https://www.theguardian.com/world/2018/oct/24/rohingyagenocide-isstill-going-on-says-top-un-investigator. 
proceedings. In fact, the Gambian Justice Minister Abubacarr Tambadou was personally motivated by his first-hand witnessing of the plight and suffering of the Rohingya refugees in Bangladesh, who fled the massacre of the military in Myanmar. ${ }^{19}$ The Gambia, on 11 November 2019, initiated proceedings against Myanmar before the ICJ in relation to alleged violations of the Genocide Convention. ${ }^{20}$ The Rohingya Genocide case (The Gambia v Myanmar) will take several years to be determined. Pending the proceedings on the merits, The Gambia also asked the Court to decide on "provisional measures" to protect the Rohingya from any further genocidal acts. ${ }^{21}$

\section{ORDER OF THE COURT ON THE ISSUE OF STANDING AND OBLIGATIONS ERGA OMNES PARTES}

The issue which is directly relevant to the present study is whether The Gambia had the legal standing to institute proceedings against Myanmar. Myanmar argued that The Gambia had no capacity to bring a case before the Court in relation to Myanmar's alleged breaches of

19 Ryan Bocock, "The Gambia, Myanmar and the International Court of Justice - A Path to Justice?" International Law Under Construction, 9 December 2019, https://grojil.org/2019/12/09/the-gambia-myanmar-andthe-international-court-of-justice-a-path-to-justice/.

20 Convention on the Prevention and Punishment of the Crime of Genocide (adopted 9 December 1948, entered into force 12 January 1951), 78 UNTS 277 [hereinafter "Genocide Convention"]. See Application Instituting Proceedings and Request for Provisional Measures, filed in the Registry of the Court on 11 November 2019, Application of the Convention on the Prevention and Punishment of the Crime of Genocide (The Gambia v Myanmar), 2019 General List No. 179, the International Court of Justice, p. 4, para. 2. The Gambia's legal team includes eminent international lawyers such as H.E. Abubacarr Marie Tambadou, Attorney General and Minister of Justice, Republic of The Gambia, Philippe Sands, QC, Professor of International Law at University College London, and Payam Akhavan, Professor of International Law, McGill University. Myanmar has hired an eminent international criminal law and genocide expert, Professor William Schabas from Canada in their legal team. Professor Schabas is the author of Genocide in International law: The Crime of Crimes (Cambridge University Press, $2^{\text {nd }}$. ed. 2009), and The International Criminal Court: A Commentary on the Rome Statute (Oxford University Press, 2010).

21 This is in accordance with Article 41 of the Statute of the ICJ. 
the Genocide Convention without being specially affected by such alleged violations. ${ }^{22}$ On the other hand, The Gambia contended that the fact of being a party to the Genocide Convention, whose obligations are erga omnes partes, by itself is sufficient to establish its legal standing before the Court, without having to prove special interest. ${ }^{23}$

After referring to relevant authorities, the ICJ decided:

Any State party to the Genocide Convention, and not only a specially affected State, may invoke the responsibility of another State party with a view to ascertaining the alleged failure to comply with its obligations erga omnes partes, and to bring that failure to an end.... The Gambia has prima facie standing to submit to it the dispute with Myanmar on the basis of alleged violations of obligations under the Genocide Convention. ${ }^{24}$

Finally, the Court, on 23 January 2020, unanimously issued its decision and indicated provisional measures to protect the Rohingya from genocide. $^{25}$

What is of vital interest to international lawyers is the ruling of the world court on the nexus between the standing before the court and the concept of obligations erga omnes partes, a fascinating rule of contemporary international law. Nonetheless, the court has not elaborated the modalities of and the specific requirements for such an obligation erga omnes partes. Many points are still moot.

\section{THE RISE OF OBLIGATIONS ERGA OMNES (FROM BILATERALISM TO COMMUNITY INTEREST)}

Actio popularis has its origin in Roman law and it refers to "an action that could be brought by an individual on behalf of the public

22 Application of the Convention on the Prevention and Punishment of the Crime of Genocide (The Gambia v Myanmar), Request for the Indication of Provisional Measures, Order of 23 January 2020, ICJ Reports 2020, 3 [Hereinafter referred to as "The Gambia v Myanmar"], at para 39.

23 The Gambia v Myanmar, para. 40.

24 The Gambia v Myanmar, paras. 41 and 42.

25 Ibid., para 86. 
interest". ${ }^{26}$ The idea of actio popularis appears to have entered the formal lexicon of international law in the South-West Africa cases in 1962. In the ICJ's 1962 South-West Africa cases (Preliminary Objections), the issue was whether Ethiopia and Liberia had standing before the ICJ over South Africa's alleged breaches of the terms of the Mandate. The International Court of Justice decided by 8 to 7 majority that the applicant States had the standing before the court as it was for the "common interest."

However, in the second phase of the South-West Africa Cases in 1966, the controversial and widely divided decision ( 7 to 7 with the casting vote of the President) reversed the previous finding and decided that although actio popularis (action based on common or communal interest) could be accepted in certain national systems of law, "it is not known to international law as it stands at present." 28

The 1966 South West Africa judgment was heavily criticized. First, it was thought that the issue of standing ought to have been settled in 1962 and there is no point of reconsidering it again. Second, the reference to actio popularis was viewed as unnecessary because the issue was resolved by way of treaty interpretation.

Four years after that, the ICJ in 1970 Barcelona Traction case appeared to have reversed its position on the question of legal standing. The issue before the Court was whether Belgium might bring a claim to the ICJ against Spain on behalf of Belgian shareholders of a Canadian corporation whose business was declared bankrupt by a Spanish court. ${ }^{29}$ In its now-famous dictum, the Court remarked:

An essential distinction should be drawn between the obligations of a state towards the international community as a whole, and those arising vis-à-vis another State in the field of diplomatic protection. By their very nature the former is the concern of all States. In view

26 William J. Aceves, "Actio Popularis? The Class Action in International Law," (2003) The University of Chicago Legal Forum, 353, at 356.

27 South West Africa Cases (Ethiopia v South Africa; Liberia v South Africa) (Preliminary Objections), Judgment of 21 December 1962, ICJ Reports 1962, 319.

28 South West Africa Cases (Ethiopia v South Africa; Liberia v South Africa) Second Phase, Judgment of 18 July 1966, ICJ Reports 1966, 6, at 47.

29 For a commentary on the case, see Richard B. Lillich, "Two Perspectives on the Barcelona Traction Case," American Journal of International Law, 65 (1971): 522. 
of the importance of the rights involved, all States can be held to have a legal interest in their protection; they are obligations erga omnes. ${ }^{30}$

The world Court in Barcelona Traction has made a landmark pronouncement affirming the concept of obligations erga omnes (Latin: in relation to everyone; owed towards all; owed towards the international community as a whole).

However, the view expressed in the above quotation was not received without criticism. The main objection was that the facts of the case did not justify such a far-reaching proclamation. ${ }^{31}$ It means that the pronouncement of the court is only obiter dictum. Nevertheless, since there is no doctrine of stare decisis in international law, ${ }^{32}$ just being an obiter will not affect the value of the pronouncement. As Ragazzi observed, "the value of each obiter dictum, or even of a ratio decidendi, can be based on the merits of a pronouncement considering the consequential development of the pronouncement itself." ${ }^{33}$

The concept of obligations erga omnes was reaffirmed in subsequent judgments of the ICJ, ${ }^{34}$ and is now generally regarded as

30 Case Concerning the Barcelona Traction, Light and Power Co, Limited, (Belgium v Spain) Second Phase, Judgment of 5 February 1970, ICJ Reports 1970, 3, paras 33, 34

31 Gleider Hernández, "International Court of Justice and the Concept of 'International Community'," British Yearbook of International Law 83 (2013): 13, at 32.

32 See Article 59 of the Statute of the International Court of Justice

33 Ragazzi, M. The Concept of International Obligations Erga Omnes. (Oxford: Oxford University Press, 2002), 5.

34 See, for example, Legal Consequences of the Separation of the Chagos Archipelago from Mauritius in 1965 (Advisory Opinion) 2019 ICJ Rep. 95, para 180 (25 February 2019); Accordance with International Law of the Unilateral Declaration of Independence in Respect of Kosovo (Advisory Opinion) [2010] ICJ Rep 89; Legal Consequences of the Construction of a Wall in the Occupied Palestinian Territory (Advisory Opinion) 2004 ICJ Rep. 136, para 157 (9 July, 2004) ("In the Court's view, these rules [of humanitarian law applicable in armed conflict] incorporate obligations which are essentially of an erga omnes character."); Case Concerning East Timor (Portugal v Australia) Judgment of 30 June 1995, 1995 ICJ Reports 90 (the right of peoples to 
creating a category of international obligation that allows every State to have legal standing to demand the respect of those obligations, even though they are not injured States. ${ }^{35}$

Further development of the concept of obligations erga omnes can be found in Article 48 of the International Law Commission (ILC)'s Articles on State Responsibility $2001 .^{36}$

Article 48 enunciates standing of a State, which is not an injured State, to take action in the interest of the international community. According to the commentary of the ILC, "A State which is entitled to invoke responsibility under article 48 is acting not in its individual capacity by reason of having suffered injury, but in its capacity as a member of a group of States to which the obligation is owed, or indeed as a member of the international community as a whole." ${ }^{37}$ The concept of obligations erga omnes is now well established in modern international law and demonstrates one of the main aspects of the enforcement of international law.

Article 48(1) draws a distinction between two categories of obligations:

(i) "obligations owed to a group of States and established to protect a collective interest of the group" (obligations erga omnes partes), and

self-determination... has an erga omnes character; ibid. at 102, para. 29). See also Hernandez, "A Reluctant Guardian: The International Court of Justice and the Concept of 'International Community'," British Yearbook of International Law 83 (2013): 34.

35 Santiago Villalpando, "The Legal Dimension of the International Community: How Community Interests

Are Protected in International Law," The European Journal of International Law, 21(2) (2010): 387-419,

401.

36 James Crawford, The International Law Commission's Articles on State Responsibility: Introduction, Text

and Commentaries, (Cambridge: Cambridge University Press, 2002) 257. See Article 48, the ILC's Articles on the Responsibility of States for Internationally Wrongful Acts, 2001.

37 Articles on the Responsibility of States for Internationally Wrongful Acts with Commentaries, 2001,

Yearbook of the International law Commission, 2001, Vol II, Part 2, 126, Commentary on Article 48(1). 
(ii) "obligations owed to the international community as a whole" (obligations erga omnes). ${ }^{38}$

\section{THE CONCEPT OF OBLIGATIONS ERGA OMNES PARTES: AN ESTABLISHED RULE OF CUSTOMARY INTERNATIONAL LAW?}

This section will focus on obligations erga omnes partes, the concept relied upon by the ICJ in the Gambia v Myanmar in 2020. The concept of obligations erga omnes partes (Latin: towards all States parties) can be traced back to Article 48(1)(a) of the ILC's Articles on State Responsibility. ${ }^{39}$ In its commentary, the ILC specifically refer to this type of an obligation as erga omnes partes. ${ }^{40}$

Obligations erga omnes partes are owed to all state parties to a multilateral treaty. They protect the collective interest of the state parties, rather than the interest of any individual state party. When the violation of an obligation erga omnes partes occurs, the legal interest of all State parties is affected, whether they suffer any direct injury as a result of the violation or not. Therefore, all State parties are entitled to institute proceedings against the State responsible for the breach of the obligation. ${ }^{41}$

The present section investigates whether the concept of obligations erga omnes partes has been established as a rule of customary international law. For that purpose, first, the practice of

38 Erika de Wet, "Invoking Obligations Erga Omnes in the Twenty-First Century: Progressive Developments

Since Barcelona Traction," South African Yearbook of International Law, 38 (2013): 1-19, at 3.

39 Article 48(1)(a), the ILC's Articles on the Responsibility of States for Internationally Wrongful Acts, 2001.

40 Para (6), Commentary of the ILC on Article 48, stating that "Such obligations have sometimes been referred to as "obligations erga omnes partes'." See also Prajwol Bickram Rana, "An Analysis of Principle of Erga Omnes Partes with Special Reference to the Case of Belgium v. Senegal, 2012," Khathmandu School of Law Review, 6(1) (2018): 193198, at 195.

41 Sukanya Wisedsri, "The Problem Regarding the State Parties' Common Interest for Identifying of Obligations Erga Omnes Partes," Graduate Law Journal, 13(4) (2020), 637-655, at 638. 
international courts and tribunals will be analysed and secondly, the international treaty practice will be evaluated.

\section{The practice of international courts and tribunals}

What is the position of the World Court? Looking back to the history of the international adjudication, although the concept of obligations erga omnes parties is not explicitly referred to, the notion of 'community interest' was invoked as early as in 1923 before the Permanent Court of International Justice (PCIJ) in the SS Wimbledon case, ${ }^{42}$ which dealt with the right of passage through the Kiel Canal. ${ }^{43}$

Germany denied SS Wimbledon, that carried arms and munition to be sent to Poland, entry into the Kiel Canal. In fact, "Article 380 of the Treaty of Versailles guarantees passage to vessels of commerce and war to all nations at peace with Germany." Relying on that provision, Great Britain, France, Italy and Japan argued that such refusal violated their right to passage. The PCIJ allowed the claim and decided that "the Kiel Canal has been permanently dedicated to the use of the whole world." ${ }^{44}$ The court interpreted the Treaty of Versailles in such a way as "to recognize the common interest for all States, regardless of whether they were the injured States or not". ${ }^{45}$

Belgium v. Senegal ${ }^{46}$ is the very first case in which the ICJ ruled that a State had standing before the court by virtue of the concept of obligations erga omnes partes. ${ }^{47}$ Under the Torture Convention of

$42 \quad$ S.S. Wimbledon, 1923 PCIJ (Ser. A) No. 1.

43 Crawford 'Responsibility for Breaches of Communitarian Norms: An Appraisal of Article 48 of the ILC Articles on Responsibility of States for Internationally Wrongful Acts' in Fastenrath et al (eds) From Bilateralism to Community Interest. Essays in Honour of Judge Bruno Simma (2011) at 228 .

44 S.S. Wimbledon, 28; Crawford, "Responsibility for Breaches of Communitarian Norms" 228.

45 S.S. Wimbledon, 20.

46 Questions Relating to the Obligation to Prosecute or Extradite (Belgium v Senegal) Judgment of 20 July 2012, [2012] ICJ Reports 422 [Hereinafter "Belgium v Senegal"].

47 Inna Uchkunova, "Belgium v. Senegal: Did the Court End the Dispute between the Parties?" EJIL Talk, July 25, 2012, ejiltalk.org/belgium-vsenegal-did-the-court-end-the-dispute-between-the-parties. 
1984, Senegal had an option of either to prosecute former Chadian President Hissène Habré without delay or to extradite him. Before deciding this, the court had to determine whether Belgium had standing before the court. ${ }^{48}$ In confirming Belgium's standing, the ICJ decided: "It follows that any State party to the Convention may invoke the responsibility of another State party with a view to ascertaining the alleged failure to comply with its obligations erga omnes partes ... and to bring that failure to an end. $" 49$

The culmination of course, is the recent ruling of the ICJ in The Gambia v Myanmar in 2020. The ICJ, in a rare unanimous judgment with the concurrence of all the 17 judges, confirmed that "to prevent and punish genocide under the Genocide Convention is an obligation erga omnes partes" and decided that "The Gambia had standing before the court for the alleged violation of the convention by Myanmar although it is not an injured State." 50

How about other international courts and tribunals? The European Court of Human Rights (ECHR) has also made similar observations. In Ireland v. United Kingdom, The ECHR ruled that the European Convention on Human Rights comprises more than mere reciprocal engagements between contracting States and that Article 24 of the Convention allowed Contracting States to require the observance of those obligations without having to justify an interest deriving. ${ }^{51}$

\section{International treaty practice}

In fact, Judge Jessup was correct when he remarked in his separate opinion in the 1962 South West Africa cases that, "for over a century, treaties have specifically recognized the legal interests of States in general humanitarian causes and have frequently provided procedural means by which States could secure respect for these interests." ${ }^{52}$ To name a few examples, the Minorities Treaties expressly provides for

\footnotetext{
48 Belgium v Senegal, para 42.

49 Belgium v Senegal, para. 68.

50 The Gambia v Myanmar, paras 41-42.

51 Ireland $v$. United Kingdom, 23 Eur Ct HR (Ser. B) (1976) para 239 [Emphasis added].

521962 South West Africa case (Preliminary Objections), Separate Opinion of Judge Jessup, at 425.
} 
the legal standing of all Allied Powers and members of the Council of the League of Nations to bring a case before the PCIJ where there is a "difference in opinion as to questions of law or fact arising out of any of the provisions contained therein". ${ }^{53}$

The Genocide Convention provides that, "disputes between the Contracting Parties relating to the interpretation, application or fulfilment of the present Convention, including those relating to the responsibility of a State for genocide or for any of the other acts enumerated in article III, shall be submitted to the International Court of Justice at the request of any of the parties to the dispute". ${ }^{4}$ The obligations that the Convention requires States to "fulfil" include the prohibition and criminalization of genocide within their respective territories.

Another example of a treaty providing for third-party standing irrespective of any direct material injury can be found in the Peace Treaty of Versailles to the Kiel Canal. In the case S.S. Wimbledon, the PCIJ observed that "each of the four Applicant Powers has a clear interest in the execution of the provisions relating to the Kiel Canal, since they all possess fleets and merchant vessels flying their respective flags. They are, therefore, even though they may be unable to adduce a prejudice to any pecuniary interest, covered by the terms of Article 386, paragraph I of the Peace Treaty of Versailles". ${ }^{55}$

The Constitution of the International Labour Organisation (ILO) also provides for third party standing. Article 26 of the ILO Constitution, for example, provides that, "any of the Members [of the ILO] shall have the right to file a complaint with the International Labour Office if it is not satisfied that any other Member is securing the effective observance of any Convention which both have ratified in accordance with the foregoing articles". ${ }^{56}$ Articles 29 and 31 provide that, "should the governments concerned in the complaint be unable to

53 See, for example, Article 12, Minorities Treaty Between the Principal Allied and Associated Powers (The British Empire, France, Italy, Japan, and the United States) and Poland, June 28, 1919.

54 Article IX, Convention on the Prevention and Punishment of the Crime of Genocide, 1948.

55 Article 386(1), the Peace Treaty of Versailles, 1919.

56 Article 26, Constitution of the International Labour Organization, Oct. 9, 1946, 15 U.N.T.S. 35. 
accept the recommendations made, the matter may be referred to the ICJ and the latter's decision would be final" ${ }^{57}$ The Constitution of the ILO thus envisages the legal standing of any of its Members to invoke the responsibility of another in relation to the observance of the ILO Convention before the ICJ.

The United Nations Convention on the Law of the Sea (UNCLOS) 1982 is another multilateral treaty in which one can find obligations erga omnes partes ${ }^{58}$ A striking example is the provision that "the Area and its resources are the common heritage of mankind". 59

Furthermore, in Austria v. Italy before the European Commission of Human Rights, the Commission decided, in relation to the European Convention on Human Rights, that any State party to the Convention was "empowered to bring before the Commission any alleged breach of the Convention, regardless of whether the victims of the alleged breach are nationals of the applicant State or whether the alleged breach otherwise particularly affects the interests of the applicant State". ${ }^{60}$

Again, Article 33 of the European Convention on Human Rights provides for an effective example of the standing of any party to the convention to bring legal proceedings against any other party in these terms: "Any High Contracting Party may refer to the Court any alleged

57 Articles 29 and 30, Constitution of the International Labour Organization.

58 Wolfrum 'Enforcing Community Interests Through International Dispute Settlement: Reality or Utopia?' in Fastenrath et al (eds) From Bilateral to Community interest. Essays in honor of Judge Bruno Simma (2011) 1136.

59 Article 136, United Nations Convention on the Law of the Sea (UNCLOS) (Montego Bay, 10 December 1982, 1833 UNTS 397). The "Area' means the "International Sea-Bed Area," that is "the seabed and ocean floor and subsoil thereof, beyond the limits of national jurisdiction." Ibid. Article 1(1).

60 Austria v. Italy, App. No. 788/60, 4 (1961) Yearbook of European Convention on Human Rights, 19-20 (Eur. Comm'n on H.R.); See also Ireland v. United Kingdom, 23 Eur. Ct. H.R. (ser. B) (1976) para 239. 
breach of the provisions of the Convention and the Protocols thereto by another High Contracting Party". ${ }^{61}$

The International Covenant on Civil and Political Rights (ICCPR) is another good example. The Human Rights Committee (HRC) in its General Comment No 31 emphatically states that "every State Party has a legal interest in the performance by every other State Party of its obligations" as rules concerning the basic rights of the human person are erga omnes obligations. ${ }^{62}$

None of the examples above require that a State must have a "direct material interest" in the subject matter of the dispute. It can, therefore, be concluded that although the ILC has adopted the concept of obligations erga omnes partes as a progressive development of international law, the concept has already been established as a rule of customary international law by virtue of widespread practice of States and opinio juris. This is a fact that is reflected in a number of multilateral conventions and decisions of international courts and tribunals, culminating in the recent judgment of the ICJ in The Gambia v Myanmar.

\section{OBLIGATIONS ERGA OMNES PARTES: CHARACTERISTICS AND MODALITIES}

In its commentaries, the ILC articulates that:

"Under Article 48(1)(a) States other than the injured State may invoke responsibility if two conditions are met: first, the obligation whose breach has given rise to responsibility must have been owed to a group to which the State invoking responsibility belongs; and secondly, the obligation must have been established for_the protection of a collective interest" ${ }^{63}$

61 Article 33, Convention for the Protection of Human Rights and Fundamental Freedom, (as amended by Protocols No 11 and 14), Nov. 4, 1950, ETS 5.

62 Human Rights Committee, General Comment No 31 [80] "Nature of the General Legal Obligation Imposed on States Parties to the Covenant" CCPR/C/21/Rev.1/Add.13 of 26 May 2004, para 2 [Emphasis added].

63 Commentary (6) to Article 48, Articles on Responsibility of States for Internationally Wrongful Act with commentaries, 2001, Yearbook of the International Law Commission, 2001, vol. II, Part Two, [Hereinafter 
According to the ILC, the obligations coming within the scope of Article 48(1)(a) have to be 'collective obligations' ${ }^{64}$

Such a "collective obligation" can be exemplified in article 194(1) of the United Nations Convention on the Law of the Sea 1982, which provides that, "States shall take, individually or jointly as appropriate, all measures consistent with this Convention that are necessary to prevent, reduce and control pollution of the marine environment from any source...." ${ }^{65}$ If there is a breach of that obligation by a State, any State parties to the Convention has a legal interest and also standing to invoke responsibility of the wrong-doer State under Article 48 as this is a collective obligation, an obligation erga omnes partes.

This type of collective obligations or obligations of common interest can be found in treaties relating to the protection of the environment, security of a region, regional nuclear-free-zone, or a regional system for the protection of human rights. ${ }^{66}$ For example, in Wimbledon case, the PCIJ noted the intention of the authors of the Treaty of Versailles to facilitate access to the Baltic by establishing an international regime, and consequently to keep the canal open at all times to foreign vessels of every kind. This is a very clear example of common (collective) interest. ${ }^{67}$

\section{How to identify obligations erga omnes partes?}

Although the Gambia v Myanmar is the most recent case and the one that reaffirms the nexus between obligation erga omnes partes and standing before the ICJ, the court in that case just applied the concept

"Articles on Responsibility of States with Commentaries"] p. 126 [Emphasis added].

64 Commentary (7) to Article 48, ibid.

65 Article 194, the UN Convention on the Law of the Sea, 1982.

66 See Commentary (7) to Article 48, Articles on Responsibility of States with Commentaries, p. 126.

67 See S.S. Wimbledon (U.K., Fr., It., and Japan v. Ger.), Judgment of 17 August 1923, 1923 PCIJ (Ser. A) No. 1, p. 23. 
by quoting Belgium $v$ Senegal, ${ }^{68}$ without going into details about its modalities and complicacies.

The notion of obligations erga omnes partes was first expressly endorsed by the ICJ in the case Belgium v. Senegal. In this case, victims of Chad nationality instituted proceedings in the Belgian courts to prosecute Hissan Habré, the former president of Chad, who was alleged to have committed gross human rights violations. After the government was overthrown, Habré took refuge in Senegal. After Senegal's rejection of requests made by Belgium for the extradition of Habré, Belgium brought a case against Senegal before the ICJ asking the Court to order Senegal to commence investigations against Habré for his crimes, on the basis that they were both parties to the United Nations Convention against Torture (UNCAT).

In Belgium $v$ Senegal, the issue before the ICJ was whether Belgium as a State party to the UNCAT had legal standing before the Court in the absence of a special interest. The ruling of the court on this issue is of paramount importance to identify the characteristics of obligations erga omnes partes. ${ }^{69}$ The court's observations can be deduced into the following two-stage test to be applied in identifying obligations erga omnes partes:

(i) First, one must seek to ascertain the object and purpose of the Convention and therefore the community interest that the treaty seeks to secure.

(ii) Second, one needs to determine whether the obligation at issue was incorporated to fulfil this purpose.

Applying the above test to the Convention against Torture, the Court found that the objective of the convention is provided in its Preamble: "to make more effective the struggle against torture ... throughout the world" and that there is therefore a "common interest to ensure that acts of torture are prevented and that their authors do not enjoy impunity." In this case, the Court decided that the "obligations of a State party to conduct a preliminary inquiry into the facts (Art 6(2) and to submit the

68 Questions Relating to the Obligation to Prosecute or Extradite (Belgium v. Senegal), Judgment of 20 July 2012, 2012 ICJ Rep. 422 [hereinafter "Belgium v. Senegal").

69 See ibid., para 69. 
case to its competent authorities for prosecution (Art 7(1)" are essential to fulfilling the object and purpose of the treaty and therefore all States parties ought to have a legal interest in others' compliance with the obligation.

\section{Can obligations erga omnes partes be found in all types of treaties?}

It is generally accepted that human rights treaties provide for obligations erga omnes partes, given that most, if not all, human rights treaties provide for obligations that are non-bilateralizable or "nonsynallagmatic"? ${ }^{70}$ United Nations Committee on the Elimination of Racial Discrimination observed that, "the jurisprudence of the European and Inter-American systems of protection of human rights, as well as the General Comment of the Human Rights Committee, shows that the objective or non-synallagmatic nature of the substantive obligations contained in the European and American Convention of Human Rights has as a result that any State party may trigger the collective enforcement machinery created by the respective treaty, independently from the existence of correlative obligations between the concerned parties". ${ }^{71}$

There is a common misunderstanding that obligations erga omnes partes can be found in human rights treaties only. Nonetheless, what is clear is that, "since all multilateral treaties have an object and purpose, the practical application of obligations erga omnes partes may extend beyond human rights treaties and beyond treaties that are nonreciprocal in character". For instance, they may even apply to free trade agreements. ${ }^{72}$

70 Non-synallagmatic means 'non-reciprocal.' In civil law systems, a synallagmatic contract is a contract in which each party to the contract is bound to provide something to the other party. The contract is reciprocal.

71 Inter-State Communication submitted by the State of Palestine against Israel, UN Committee on the Elimination of Racial Discrimination, U.N. . CERD/C/100/5 (2019), para. 3.33.

72 See, for example, Chios Carmody, "WTO Obligations as Collective," European Journal of International Law

17 (2006): 419; Joost Pauwelyn, "A Typology of Multilateral Treaty Obligations: Are WTO Obligations Bilateral or Collective in Nature," European Journal of International Law, 14 (2003): 907. 
The decisive factor is that they must be collective obligations and must be established for common or collective interest of a group of States. As already stated earlier, obligations erga omnes partes can be found in various types of multilateral treaties, such as in the areas of law of the sea, environmental protection, nuclear free zone, and so on.

\section{Do all provisions in a multilateral treaty constitute obligations erga omnes partes?}

Obligations erga omnes partes can as a rule be found in multilateral treaties. One difficult question that can be raised is: are all substantive provisions of a treaty obligations erga omnes partes?

It is generally accepted that human rights treaties may create obligations erga omnes partes. It has been argued that since human rights treaties are not concluded on the basis of reciprocity, they are a "series of unilateral engagements solemnly contracted before the world as represented by the other Contracting Parties". If this characterization were accurate, then prima facie all obligations pertaining to human rights treaties would be erga omnes partes in nature. ${ }^{73}$

However, many commentators are of the view, "that there are indeed multilateral treaties in which their performance in a given situation involves a relationship of a bilateral character between two parties and that multilateral treaties of this kind have often been referred to as giving rise to bundles of bilateral relations." ${ }^{14}$ This is the

73 See U.N. Human Rights Committee, General Comment No. 31: The Nature of the General Legal Obligation Imposed on States Parties to the Covenant, U.N. Doc. CCPR/C/21/Rev.1/Add.13, para 2 (2004); Erika De Wet, "The International Constitutional Order," International and Comparative law Quarterly, 55 (1) (2006), 51-76, at 55.

74 See, for example, K. Sachariew, "State Responsibility for Multilateral Treaty Violations: Identifying the 'Injured State' and its Legal Status," Netherlands International Law Review, 35 (3) (1988), 273, at 277-278; B. Simma, "Bilateralism and Community interest in the Law of State Responsibility", International Law at a Time of Perplexity: Essays in Honour of Shabtai Rosenne, Y. Dinstein, ed. (Dordrecht, Martinus Nijhoff, 1989), 821, at 823; C. Annacker, "The Legal Régime of Erga Omnes Obligations in International Law," Austrian Journal of Public and International Law, 46(2) (1994), 131, at 136; and D. N. Hutchinson, 
reason why in Belgium $v$ Senegal the ICJ implied that obligations erga omnes partes are non-bilateralizable obligations "owed by any State party to all the other States parties to the Convention". ${ }^{75}$

In Belgium v Senegal, the Court decided that the "obligations of a State party to conduct a preliminary inquiry into the facts and to submit the case to its competent authorities for prosecution are essential to fulfilling the aim of the treaty and therefore all States parties ought to have a legal interest in others' compliance with these obligations." "76 Judge Donoghue, in his Declaration in support of the judgment, put it succinctly, "I conclude that the duties imposed by Article 6(2), and Article 7(1), of the Convention against Torture are duties erga omnes partes. This characterization may not fit every provision of the Convention". ${ }^{77}$

It is true as the convention contains a wide list of provisions in relation to the prevention and prohibition of torture, including Articles 10 and 11 on the obligation to ensure that education and information regarding the prohibition of torture are fully integrated into the training of law enforcement officers and the obligation to keep a systemic review of interrogation rules. ${ }^{78}$ It would indeed be rather ridiculous if one considers such minor obligations that are not essential to the fulfilment of the object and purpose of the treaty obligations erga omnes partes.

The better view that is supported by the dictum of Belgium $v$ Senegal, therefore, is that not all provisions in a multilateral treaty may create obligations erga omne partes. Only those provisions that are essential to the object and purpose of the treaty may be considered obligations erga omnes partes.

"Solidarity and Breaches of Multilateral Treaties", British Yearbook of International Law, 59 (1988), 151, at 154-155.

75 Belgium v. Senegal, at 68.

76 Ibid.

77 See also Belgium v. Senegal, Declaration by Judge Donoghue, para 12.

78 Articles 10 and 11, Convention Against Torture, 1984. 


\section{Standing versus jurisdiction}

It is important to clarify that the practical application of obligations erga omnes partes relates solely to standing ${ }^{79}$ which is in turn an aspect of admissibility. ${ }^{80}$ Furthermore, obligations erga omnes partes do not relate to jurisdiction. The difference between standing and jurisdiction has been acknowledged in a series of ICJ cases. In Armed Activities, the Democratic Republic of Congo alleged that Rwanda had violated the Genocide Convention. Rwanda, however, made a reservation to Article IX of the Convention (the compromising clause). The Court took the view that "the mere fact that rights and obligations erga omnes may be at issue in a dispute would not give the Court jurisdiction to entertain that dispute ...." 81

In East Timor, after affirming the erga omnes character of the right to self-determination, the ICJ remarked that "the Court considers that the erga omnes character of a norm and the rule of consent to jurisdiction are two different things. Whatever the nature of the obligation invoked, the Court could not rule on the lawfulness of the conduct of a State when its judgment would imply an evaluation of the lawfulness of the conduct of another State which is not a party to the case. Where this is so, the Court cannot act, even if the right in question is a right erga omnes." $" 82$

In order to bring a claim against a respondent State on the ground of a breach of an obligation erga omnes partes, not only must the court have jurisdiction to adjudicate upon the dispute, but all other aspects of

79 Both obligations erga omnes and erga omnes partes relate strictly to legal standing. See Legal Consequences of the Construction of a Wall in the Occupied Palestinian Territory, Advisory Opinion (July 9, 2004), 2004 ICJ Rep. 136, Separate Opinion of Judge Higgins, para. 37.

80 See Abaclat and Others v. Argentina Republic, ICSID Case No. ARB/07/5, Decision on Jurisdiction and Admissibility (August 4, 2011), Dissenting Opinion of Georges Abi-Saab, para. 126.

81 Armed Activities on the Territory of the Congo (New Application: 2002) (Dem. Rep. Congo v. Rwanda), Judgment of 19 December 2005, 2005 ICJ Rep. 168, Separate Opinion of Judge Simma, para. 34.

82 East Timor (Port. v. Austl.) (Judgment of 30 June 1995), 1995 ICJ Rep. 90 . 
admissibility (nationality of claims, exhaustion of local remedies, etc.) must also be met. ${ }^{83}$

\section{CONCLUSION}

The Roman law idea of actio popularis was a concept based on the protection of community interest that is the hallmark of natural law theory. However, in the controversial decision of 1966 South West Africa cases, the ICJ rejected the idea of actio popularis in international law. Again, when the ICJ first recognized the concept of obligations erga omnes in 1970 Barcelona Traction case, there was much reluctance from the international legal fraternity to accept such an innovative idea. This is not at all surprising as positivism has been the mainstream legal thinking of the contemporary international law.

After many years of research and deliberations, the International Law Commission, in their well-respected Articles on Responsibility of States for internationally Wrongful Act 2001, not only affirms the concept of obligations erga omnes but also introduces the concept of obligations erga omnes partes, the latter being an offshoot of the former. Although the ILC introduced the concept of obligations erga omnes partes as a progressive development of international law, the idea had been accepted in international jurisprudence as early as 1923 in S.S. Wimbledon case.

With the revival of natural law theory in the contemporary world, the acceptance by the international community of jus cogens (peremptory norms from which no derogation is permitted), and the universal recognition of international human rights instruments and international crimes, the concept of obligations erga omnes partes has been well received by the international community. It is affirmed by the ICJ in Belgium v Senegal in 2012 and reaffirmed with a unanimous decision of the ICJ in the The Gambia v Myanmar in 2020.

The analysis in the earlier sections has shown that the concept of obligations erga omnes partes has been established as a rule of customary international law, creating standing for any state party to the

83 Application of the Convention on the Prevention and Punishment of the Crime of Genocide (Croat. v. Serb.) (Preliminary Objections), Judgment, 2008 ICJ Rep. 456, para. 120. 
treaty, that it can be found not only in human rights treaties but also in many other types of treaties, and that only those provisions that are essential to the object and purpose of the treaty may be considered obligations erga omnes partes. 